\title{
The role of Fc gamma receptors in the activity of immunomodulatory antibodies for cancer
}

\author{
Ross Stewart ${ }^{1 *}$, Scott A Hammond ${ }^{2}$, Michael Oberst ${ }^{2}$ and Robert W Wilkinson ${ }^{1}$
}

\begin{abstract}
Antibodies targeting T-cell inhibitory pathways, such as CTLA-4 and PD-1/PD-L1, are emerging as an important class of cancer therapeutics, and a next generation of immunomodulatory therapies targeting alternative inhibitory (e.g. TIM-3, LAG-3, B7-H4, B7-H3, VISTA, A2aR), as well as co-stimulatory (e.g. CD27, OX40, GITR, CD137), pathways are poised to join them. Most of these immunomodulatory antibodies are of lgG isotypes that have low, or no, binding to the Fc gamma receptors (FcyRs) that trigger cell-mediated cytotoxic effector functions such as antibody dependent cellular cytotoxicity (ADCC) and phagocytosis (ADCP). These isotypes were selected to minimise the risk of depleting the T cells upon which such antibodies depend for their mechanism of action. However, recent preclinical data highlight a potential role for FcyR engagement in the activity of such antibodies. Here we review the biology of the FcyRs and IgG isotypes in both humans and mice, detail the potential roles that FcyR interactions can play in the activity of monoclonal antibodies in general, and of immunomodulatory antibodies in particular, and discuss how preclinical studies on these interactions might be best interpreted and translated to a human setting.
\end{abstract}

Keywords: Fc gamma receptors, Anti-CTLA-4, Anti-GITR, Immunomodulatory antibodies

\section{Introduction}

Antibodies of the IgG sub-class are bi-functional molecules, possessing a $\mathrm{F}(\mathrm{ab})$ domain, variable in sequence and responsible for the binding of antigen, and an Fc domain, constant in sequence and responsible for mediating a range of antibody effector functions [1]. These functions are primarily triggered through interaction with the complement component $\mathrm{C} 1 \mathrm{q}$ or with a family of $\mathrm{Fc} \gamma \mathrm{Rs}$ expressed, primarily, on the surface of leukocytes. Each IgG isotype has a different binding profile to the various $F c \gamma R s$, and each $F c \gamma R$ has a different cellular expression pattern. These differences enable the breadth, flexibility and control of function required to mount an effective and regulated humoral response.

Effector functions mediated by the Fc $\gamma$ Rs, such as ADCC and ADCP, are believed to play an important role in the activity of several therapeutic antibodies; including a number used in Oncology, for example rituximab and trastuzumab. Antibodies targeting T-cell inhibitory pathways, such as CTLA-4 and PD-1/PD-L1, are emerging as an important class of cancer therapeutics, and a next generation of immunomodulatory therapies targeting alternative inhibitory (e.g.

\footnotetext{
* Correspondence: stewartr@medimmune.com

'Medlmmune, AKB Building, Granta Park, CB21 6GH England, UK

Full list of author information is available at the end of the article
}

TIM-3, LAG-3, B7-H4, B7-H3, VISTA, A2aR), as well as co-stimulatory (e.g. CD27, OX40, GITR, CD137), pathways are poised to join them. In contrast to agents such as rituximab, most of these immunomodulatory antibodies are of IgG isotypes that have low, or no, binding to the Fc gamma receptors (Fc $\gamma R s$ ), and effects such as $A D C C$ have not been considered to be critical to their activity. Recent studies in mice have, however, highlighted a potential role for $\mathrm{Fc} F \mathrm{R}$ binding, and $\mathrm{F} c \gamma \mathrm{R}$ mediated effector functions in the activity of antibodies targeting a number of these pathways.

Below we review the findings of these recent studies and discuss how they may change our understanding of the role Fc $\gamma R$ interactions play in the activity of immunomodulatory antibodies in mice. We begin, however, by reviewing the biology of the FcyRs and IgG isotypes in mice and humans, highlighting the key similarities and differences, which need to be appreciated when thinking about how to translate these findings to a human setting, in order to select the optimal isotype for any potential therapeutic.

\section{Review}

The Fc gamma receptor family

Humans and mice possess two classes of FcyRs, the activating and inhibitory receptors. In both species Fc $\gamma$ RI is 
an activating receptor with high affinity for IgG, and is expressed on monocytic DCs and on monocytes/macrophages broadly in humans but in select locations in mouse (Table 1) [2,3]. FcyRI is the only FcyR with a functionally meaningful binding affinity for monomeric IgG, the remaining FcyRs all exhibit such low affinity for the Fc region of IgG that functional engagement is only expected to occur upon binding of antibody complexed through antigen engagement (Table 2). Both species possess a single inhibitory FcyR, Fc $\gamma$ RIIb, which is expressed on B cells, DCs and basophils in both species, and found additionally on monocytes, macrophages and all granulocyte populations in mice (Table 1). The remaining FcyRs are all activating, but more divergent between species. In mice there are only 2 additional activating receptors FcyRIII, which is expressed broadly on NK cells, monocytes, macrophages, granulocytes and DCs, and FcyRIV, which is found only on monocytes, macrophages and neutrophils. In humans there are four additional activating Fc $\gamma$ Rs, the best characterised being Fc $\gamma$ RIIa and Fc $\gamma$ RIIIa. FcyRIIa is expressed on granulocytes, monocytes and monocyte-derived cells such as macrophages and DCs. FcyRIIIa is expressed primarily on NK cells, but is also found on monocytes and macrophages under some circumstances (Table 1). Each of these receptors exists as two allotypic variants with differing binding affinity for IgG (Table 2). For FcyRIIIa the more common F158 allotype has a lower affinity than the V158 allotype. For FcyRIIa the more common H131 allotype has a higher affinity than the R131 allotype [4]. The other two activating receptors are far less well characterised. Fc $\gamma$ RIIc is expressed in only $20 \%$ of people and is closely related to, but expressed more restrictedly than, Fc $\gamma$ RIIa. Fc $\gamma$ RIIIb is a GPI linked receptor expressed mainly on the surface of neutrophils.

Mice and humans also have a divergent family of IgG isotypes. In humans there are 4 isotypes, IgG1-4, each of which has differing binding affinities to the various Fc $\gamma$ Rs. Human (h)IgG3 demonstrates relatively high affinity binding to most FcyRs, but is not used routinely as a therapeutic format (due to its long hinge region and polymorphic nature which represent a stability and immunogenicity risk respectively) and will not be considered further in this review. Of the remaining isotypes hIgG1 demonstrates the highest affinity for FcyRs, with a $\mathrm{nM}$ or low $\mu \mathrm{M}$ binding affinity to all receptors (estimated by surface plasmon resonance [SPR]), and is considered a potent inducer of all cell mediated effector functions, such as ADCC and ADCP. hIgG4 demonstrates a nM affinity for $F c \gamma R I$ but $\mu \mathrm{M}$ affinities for all other receptors and is considered a poor inducer of such effector functions. hIgG2 has no measurable affinity for FcyRI, a high nM affinity for the H131 form Fc $\gamma$ RIIa and $\mu \mathrm{M}$ affinities for all other FcyRs (Table 2).

These absolute affinities are a useful guide as to the binding of the hIgG isotypes to hFc $\gamma$ Rs relative to each other. However, as noted above, the functional interaction between IgG and most FcyRs is not monomeric in nature, as is modelled by SPR. In a study [5] examining the more functionally relevant binding of complexed IgG to FcyRs on cells, the relative ranking of the isotypes with respect to $\mathrm{Fc} \gamma \mathrm{R}$ binding was retained, however no binding of IgG2 to cells expressing the inhibitory FcyRIIb or the F158 form of the activating FcyRIIIa could be detected using this methodology, despite the interaction between IgG2 and these proteins demonstrated by SPR.

Mice also have four IgG isotypes but they are not equivalent to those of human in either nomenclature or properties. Mouse (m)IgG1, in contrast to hIgG1, is considered a low effector function isotype, since while it binds inhibitory Fc $\gamma$ RIIb and activating Fc $\gamma$ RIII with nM affinity, it has no measurable binding to activating Fc $\gamma$ RIV. In mice it is the two IgG2 isotypes, mIgG2a and mIgG2b, that have the highest binding affinities to FcyRs, particularly to FcyRIV (Table 2). In mice there is no IgG4 isotype, and mIgG3 has no measurable FcyR interactions [6].

These differences in $F c \gamma R$ and antibody isotype interactions and expression, summarised in Tables 1 and 2, mean that there are no direct homologs between human and mouse with respect to $\mathrm{Fc} \gamma \mathrm{R}$ and antibody isotype biology. However, it is possible to draw some parallels between the species, for example mIgG2a and hIgG1 are often considered equivalent functionally due to their broad and high FcyR binding, while the generally lower

Table 1 Expression pattern of the major FcyRs in human and mouse

\begin{tabular}{|c|c|c|c|c|c|c|c|c|}
\hline \multirow[t]{2}{*}{ Cell type } & \multicolumn{2}{|c|}{ FcyRI } & \multicolumn{2}{|c|}{$F c \gamma R \| l b$} & \multirow[t]{2}{*}{ hFcyRIla } & \multirow[t]{2}{*}{$\mathrm{mF} c \gamma \mathrm{RIII}$} & \multirow[t]{2}{*}{ hFcyRIIla } & \multirow[t]{2}{*}{ mFcyRIV } \\
\hline & $\mathrm{h}$ & m & $\mathbf{h}$ & $\mathrm{m}$ & & & & \\
\hline B cells & & & + & + & & & & \\
\hline DCs & + & + & + & + & + & + & & \\
\hline NK cells & & & & & & + & + & \\
\hline Monocytes/Macrophages & + & $\sim$ & $\sim$ & + & + & + & + & + \\
\hline Neutrophils & $(+)$ & & $\sim$ & + & + & + & & + \\
\hline
\end{tabular}

Italics indicates an inhibitory receptor. Normal text indicates an activating receptor. Human receptors are denoted by $\mathrm{h}$ and mouse receptors by $\mathrm{m}$. + indicates expression, $(+)$ indicates inducible expression and $\sim$ indicates expression on only a sub-set or on cells at specific physiological locations [2,3]. 
Table 2 Relative affinity of binding between the major FcyRs and IgG Isotypes in human and mouse

\begin{tabular}{|c|c|c|c|c|c|c|c|c|}
\hline \multicolumn{5}{|c|}{ Human } & \multicolumn{4}{|c|}{ Mouse } \\
\hline \multicolumn{2}{|c|}{ FcyR } & $\operatorname{lgG1}$ & $\operatorname{lgG} 2$ & $\operatorname{lgG4}$ & FcyR & IgG1 & $\operatorname{lgG} 2 a$ & $\lg G 2 b$ \\
\hline \multicolumn{2}{|l|}{ 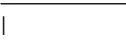 } & ++++ & - & ++++ & 1 & - & ++++ & +++++ \\
\hline \multirow[t]{2}{*}{ Ila } & $\mathrm{H}_{131}$ & +++ & ++ & ++ & III & ++ & ++ & ++ \\
\hline & $R_{131}$ & +++ & + & ++ & & & & \\
\hline \multicolumn{2}{|l|}{116} & ++ & - & ++ & $\| B$ & +++ & ++ & +++ \\
\hline \multirow[t]{2}{*}{ Illa } & $V_{158}$ & +++ & + & ++ & IV & - & +++ & ++ \\
\hline & $F_{158}$ & ++ & - & ++ & & & & \\
\hline
\end{tabular}

Italics indicates an inhibitory receptor. Normal text indicates an activating receptor. Rankings are based on $\mathrm{K}_{\mathrm{A}} \times 10^{5} \mathrm{M}^{-1}$ for each interaction reported in published studies $[1,5,6]$. ++++ indicates a $\mathrm{K}_{\mathrm{A}}$ greater than $100 \times 10^{5} \mathrm{M}^{-1}$, +++ indicates a $\mathrm{K}_{\mathrm{A}}$ between 20 and $99 \times 10^{5} \mathrm{M}^{-1},++$ indicates a $\mathrm{K}_{\mathrm{A}}$ between 1 and $19 \times 10^{5} \mathrm{M}^{-1}$, + indicates a $\mathrm{K}_{\mathrm{A}}$ between 0.5 and $0.9 \times 10^{5} \mathrm{M}^{-1}$, - indicates a $\mathrm{K}_{\mathrm{A}}$ that was undetectable or less than $0.5 \times 10^{5} \mathrm{M}^{-1}$.

and more select binding profiles of mIgG1 and hIgG4 make them close functional analogs. Additionally the activating $\mathrm{mFc} \gamma \mathrm{RIII}$ and $\mathrm{hFc} \gamma \mathrm{RIIa}$ are often considered analogous based on affinities and expression pattern, as are activating $\mathrm{mFc} \gamma \mathrm{RIV}$ and $\mathrm{hFc} \gamma \mathrm{RIII}$. These parallels are frequently imperfect though, for example: hFc $\mathrm{RIIIa}$ is expressed at high levels on NK cells, while mFcyRIV is not; hFcrRIIa is not expressed on NK cells while $\mathrm{mFc} \gamma \mathrm{RIII}$ is; $\mathrm{mIgG1}$ is a more functionally restricted isotype than hIgG4, based on their relative affinities for activating Fc $\gamma R I, m F c \gamma R I V$ and $h F c \gamma R I I a$. These differences need to be kept in mind, and pose challenges, when trying to translate findings in mouse preclinical models to humans.

\section{The potential roles of FcyRs in the activity of therapeutic antibodies}

The Fc $\gamma \mathrm{R}$ mediated functions most commonly associated with therapeutic antibodies are those that mediate target cell elimination; ADCC, or the related ADCP. These functions are triggered when antibody binding to antigen on the surface of a target cell generates sufficient avidity to trigger signalling through FcyRs on effector cells such as NK cells and macrophages, which then eliminate target cells through direct killing or phagocytosis (Figure 1, left). Preclinical models show that these forms of FcyRmediated cytotoxicity are a significant component of the mechanism of action for tumor targeted antibodies such as the anti-CD20 antibody rituximab and the anti-HER2 antibody trastuzumab [7]. The clinical evidence for the role of such interactions, however, is more mixed. A number of relatively small studies have shown improved outcomes in patients that are homozygous for the higher affinity allotypic forms of human FcyRIIIa and FcyRIIa $[8,9]$, supporting a role for Fc $\gamma \mathrm{R}$-mediated cytotoxicity in this setting, but several larger, randomized studies have generally failed to show the same associations [4].
Nevertheless a significant effort has been made to engineer antibodies with improved affinity for the activating FcyRs [10-12], with the aim of enhancing these cytotoxic functions and improving therapeutic efficacy, and the outcome of clinical trials with such agents may provide further clarity as to the true contribution of $\mathrm{F} c \gamma \mathrm{R}$ mediated cytotoxicity in activity.

An alternative role for $\mathrm{F}_{\mathrm{c}} \mathrm{R}$ Rs is in the activity of antibodies that function by agonising cell surface receptors, for example those of the tumor necrosis factor receptor (TNFR) super family. In this context binding of IgG Fc to $\mathrm{Fc} \gamma \mathrm{Rs}$ results in higher order clustering of antibody. This in turn results in higher order clustering of the target receptor when bound by the $\mathrm{F}(\mathrm{ab})$ domain, which triggers downstream signalling (Figure 1, right). This clustering effect has been shown to be critical to the activity of antibodies specific for the TNFR family members CD40 $[13,14]$ death receptor 5 (DR5) [15,16] and CD95 (Fas) [17] in preclinical mouse models, and has been suggested to play a similar role in the activity of other TNFR agonists such as anti-OX40 and anti-CD27 [18].

\section{The canonical role of FcyRs in immunomodulatory antibodies}

Immunomodulatory antibodies mediate their beneficial effects by promoting anti-tumor immunity. There are a number of potential ways to achieve this, but one area showing particular promise is the use of antibodies that antagonise inhibitory receptors on the surface of $\mathrm{T}$ cells. One such antibody, the anti-CTLA-4 ipilimumab, was approved based on its ability to improve survival in metastatic melanoma patients [19], while a number of antibodies targeting PD-1 are showing highly encouraging results in phase 1 clinical trials [20,21]. An alternative approach, which is earlier in clinical development but also showing promise, is the use of antibodies that agonise co-stimulatory receptors. The agonistic anti-CD40 antibody, CP870,893, has demonstrated early signs of activity in pancreatic cancer [22], and tumor shrinkage was also observed in some patients treated with agonistic antibodies directed against OX40 [23] and CD137 [24].

As mentioned above $\mathrm{F}_{\mathrm{c} \gamma \mathrm{R}}$ engagement has been shown to be critical for the activity of antibodies that agonise the TNFR CD40 in mice. The anti-tumor activity of anti-mouse CD40 in these studies is lost upon introduction of the D265A mutation into its FC domain [13], which results in an antibody with no measurable Fc $\gamma R$ binding [6]. It has also been shown that the in vitro activity of antibodies directed against other TNFRs in human cells, such as OX40, GITR, CD137 and CD27, requires, or is greatly enhanced by $\mathrm{F} c \gamma \mathrm{R}$ engagement or immobilisation $[25,26]$. While the evidence suggests that a requirement for cross linking is a common property of antibodies targeting TNFRs receptors, there are some 


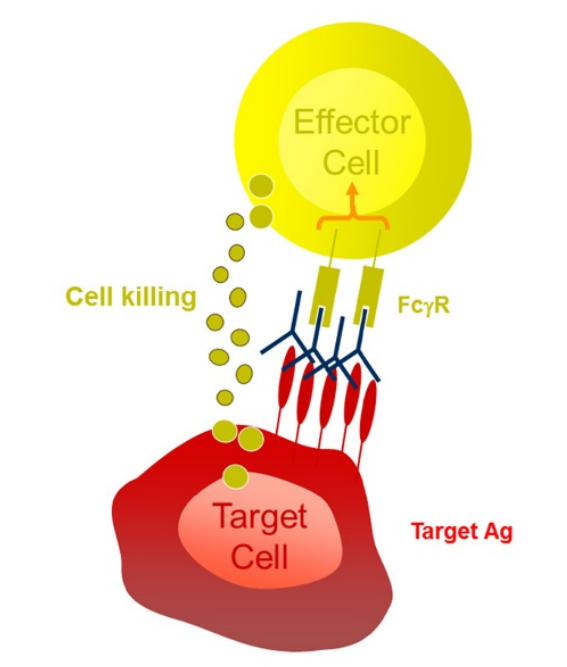

Antibody bound to High level of target antigen clusters FcyRs driving activating signals to effector cells and triggering ADCC or ADCP

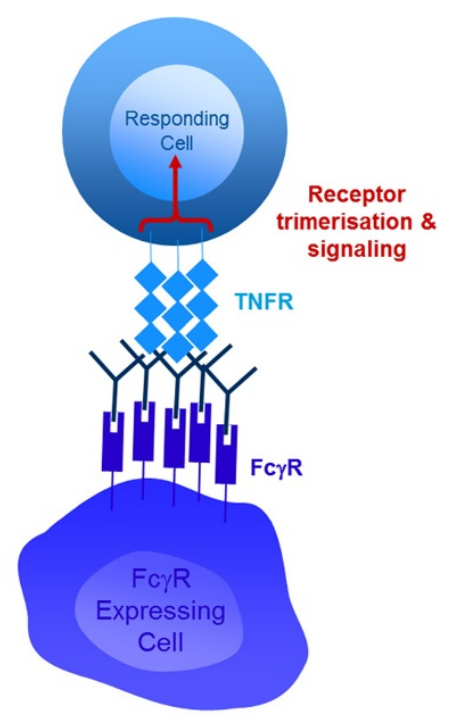

Low level of target receptor is clustered by antibody bound to FcyRs driving activating signals to receptor expressing cells

Figure 1 The two primary forms of interaction between therapeutic IgGs and FcyRs. On the left: when lgG is bound to high levels of antigen on target cells, such as tumor cells, the resulting clustered Fc domains engage with FcyRs on immune effector cells such as NK cells and macrophages. This drives signals through those FcyRs triggering the initiation of cell-mediated effector functions such as ADCC and ADCP. On the right: when IgG is bound by its Fc domain to FcyRs it can act to cluster low levels of target receptors, such as members of the TNFR family. This clustering acts to trigger signals though the TNFR into target cells, such as T cells.

exceptions. For example the hCD27.15 anti-human CD27 $\mathrm{mAb}$ has demonstrable agonistic properties in the soluble phase [27], the anti-CD40 antibody CP870,893 has been shown to function in vitro in solution and as a $\mathrm{F}(\mathrm{ab})_{2}{ }_{2}$ fragment that lacks any Fc domain [28] and the antiOX40 antibody 9B12, which is a mouse IgG1 with very low affinity interactions with FcyRs, has shown early signs of clinical activity and demonstrated the ability to activate T cells in patients [23].

Two studies that further explored the role of FcyR engagement for the activity of anti-mouse CD40 demonstrated that it is the inhibitory mouse FcyRIIb that plays an essential role $[13,14]$. One of these studies [14] went on to demonstrate that other mouse $\mathrm{F}_{\mathrm{c}} \mathrm{\gamma Rs}$ are capable of cross linking anti-CD40 to drive activity in vitro, and proposed that the dominant role of FcyRIIb in vivo was due primarily to its bioavailability at the site of action for anti-CD40, namely the secondary lymphoid organs. Both studies also went on to show that the activity of anti-mouse CD40 was lost upon class switching from a mouse (m)IgG1 to a mIgG2a. Two alternative, and nonmutually exclusive, hypotheses exist to explain this observation. The first is that the reduced affinity of mIgG2a for Fc $\gamma$ RIIb results in reduced cross linking at the relevant site of action and so limits activity [14]. The second is that the loss of activity occurs due to increased depletion of CD40 positive cells, which are predominantly antigen presenting cells (APCs) critical to mounting an adaptive immune response [13]. In the case of the second hypothesis, the balance of $\mathrm{Fc} \gamma \mathrm{R}$ engagement would become critical to the activity of anti-CD40. Too little engagement, as seen with alglycosyl antibodies, and no agonistic signalling is triggered so no anti-tumor activity is observed. Too much FcyR engagement on effector cells and depletion of critical immune cells begins to occur and antitumor activity is once again lost. Such a trade off in FcyR affinity could also apply to other immunomodulatory antibodies that target TNFRs (CD27, OX40, GITR, CD137), which are also expressed on critical immune cells. In addition it has been shown that for CD137 antibody mediated internalisation of receptor can play a role in driving signalling [29], and it is unclear how changes in Fc isotype might affect this property.

For those antibodies that target inhibitory receptors like PD-1 and CTLA-4 there has been little reason to believe, based on their antagonistic mechanism of action, that $\mathrm{F} c \gamma \mathrm{R}$ engagement plays an important role in their activity, and no significant evidence to contradict this belief exists in the clinical setting. Since all of the antigens targeted by these antibodies are expressed either on T cells or on APCs, the preference has been to select isotypes that will avoid the risk of depleting these cells through Fc mediated mechanisms; an outcome that would likely negate any beneficial immune activation. As a result, 
a common feature of the immunomodulatory antibodies currently in clinical development is that they are low or null effector function isotypes (Table 3). Main exceptions include ipilimumab (anti-CTLA-4), MSB0010718C (antiPD-L1) and antibodies like MGA271 (anti-B7-H3), CDX1127 (anti-CD27) and alemtuzumab (anti-CD52) which employ ADCC of tumor cells as a part of their mechanism of action.

However, several recent preclinical studies are calling into question the view that all TNFR agonist antibodies will behave as anti-CD40 does, or that all antibodies targeting inhibitory receptors will be maximally effective as a low or null effector function isotype.

\section{The evolving role of FcyRs in immunomodulatory antibodies}

Three recently published studies [31-33] have examined the role of mouse $\mathrm{Fc \gamma Rs}$ in the activity of anti-mouse CTLA-4 antibodies. In these studies anti-mouse CTLA-4 antibodies were studied in a range of syngeneic tumor models where they have previously shown activity, including MC38 (colon), CT26 (colon) and B16 (melanoma). The approach taken to examine the role of FcyRs varied between studies and either involved the use of Fc $\gamma \mathrm{R}$ knock out mice $[31,33]$ or reformatting of the anti-mouse CTLA4 to a variety of different antibody isotypes [32]. Irrelevant of the approach taken the result was the same; the activity of anti-mouse CTLA-4 was shown to be dependent upon engagement of the activating FcyRs in mouse tumor models. Further examination of the mechanism for this dependence revealed that in the lymph nodes anti-mouse CTLA- 4 acted to increase the number of CD4 T cells, including regulatory $\mathrm{T}$ cells (T-regs), but that within the tumor it acted to selectively deplete only T-regs [33]. In one of the three studies, a comparison of several different anti-mouse CTLA- 4 antibodies showed that the extent of T-reg depletion observed correlated with activity [33]. The depletion of T-regs was mediated predominantly by mouse FcyRIV, but was independent of NK cells, and considered likely to rely on the activity of intratumoral CD11b + macrophages [33]. In all three studies the level of CTLA-4 expression was shown to be increased on intratumoral $\mathrm{T}$ cells relative to those in lymph nodes, and was higher on T-regs than on other T cell sub-sets.

In their study Bulliard et al. [31] also examined the role of mouse FcyRs in the activity of the anti-mouse GITR antibody DTA-1. In contrast to the observations made for anti-mouse CD40, DTA-1 activity was minimally affected by the absence of inhibitory FcyRIIb, but was dependent on the presence of the activating mouse FcyRs [31]. In further contrast to anti-CD40, a mouse (m)IgG2a version of DTA-1 was equal in activity to the parental rat IgG2b version; although no mIgG1 was tested. Analogous to the mechanism observed for antimouse CTLA-4, it was shown that while mIgG2a or rat IgG2b forms of DTA-1 treatment resulted in expansion of

Table 3 List of immunomodulatory antibodies currently in clinical development and their respective isotypes

\begin{tabular}{|c|c|c|c|c|}
\hline Antibody & Target & Company & Latest active clinical phase & Isotype \\
\hline Ipilimumab & CTLA-4 & BMS & Approved & $\lg G 1$ \\
\hline Tremelimumab & CTLA-4 & Medlmmune/AstraZeneca & $\|$ & $\lg G 2$ \\
\hline Nivolumab & PD-1 & BMS & Approved & $\lg G 4$ \\
\hline MK-3475 & PD-1 & Merck & III & $\lg G 4$ \\
\hline CT-011 & PD-1 & CureTech & $\|$ & $\lg G 1$ \\
\hline MPDL3280A & PD-L1 & Genentech/Roche & III & Aglycosyl lgG1 \\
\hline MEDI4736 & PD-L1 & Medlmmune/AstraZeneca & I & $\operatorname{lgG} 1 \mathrm{TM}$ \\
\hline MDX-1105 & PD-L1 & BMS & I & $\lg G 4$ \\
\hline MSB0010718C & PD-L1 & Merck KGaA & I & $\lg G 1$ \\
\hline BMS-663513 & CD137 & BMS & । & $\lg G 4$ \\
\hline PF-05082566 & CD137 & Pfizer & I & $\lg G 2$ \\
\hline TRX518 & GITR & GITR Inc & । & Aglycosyl lgG1 \\
\hline MEDI6469 & OX40 & Medlmmune/AstraZeneca/AgonOX & 1 & Mouse $\operatorname{lgG1}$ \\
\hline CP-870,893 & CD40 & Roche & । & $\lg G 2$ \\
\hline CDX-1127 & CD27 & CellDex & । & $\lg G 1$ \\
\hline Lirilumab; IPH2102 & $\mathrm{KIR}$ & BMS/Innate Pharma & $\|$ & $\lg G 4$ \\
\hline MGA271 & $\mathrm{B} 7-\mathrm{H} 3$ & Macrogenics/Servier & । & $\lg G 1$ \\
\hline Alemtuzumab & CD52 & Genzyme/Bayer & Approved & $\lg G 1$ \\
\hline
\end{tabular}

$\operatorname{lgG1} \mathrm{TM}=\lg \mathrm{g} 1$ triple mutant, which contains 3 point mutations in the Fc domain that reduce the binding affinity of the mAb to FcyRs [30]. 
all $\mathrm{T}$ cell populations in the lymph node, they acted to deplete $\mathrm{T}$ cells within the tumor. Also similar to anti-mouse CTLA-4, this depletion preferentially occurred in the T-reg compartment and, although some reduction in both conventional $\mathrm{CD} 4+$ and $\mathrm{CD} 8+\mathrm{T}$ cells was also observed, resulted in an increase in the CD8:T-reg ratio within the tumor. In a more recent study published earlier this year Builliard et al. [34] demonstrated a comparable mechanism, and dependence on activating mouse $\mathrm{Fc} \gamma \mathrm{Rs}$ for an anti-mouse OX40 antibody. It is however worth noting that alternative studies have proposed, and evidenced, a mechanism of regulatory $\mathrm{T}$ cell re-programming for DTA-1 [35] and for anti-human OX40 mAbs [36], suggesting that a loss of FOXP3 expressing T cells following treatment with agents targeting either pathway may not necessarily equate to depletion.

These preclinical studies have brought into question two generally held beliefs regarding the role of FcyRs in the activity of immunomodulatory antibodies. The first is the idea that inhibitory FcyRIIb is the critical receptor for the activity of all TNFR agonist antibodies. The data generated for the anti-mouse GITR antibody DTA-1 clearly demonstrate FcyRIIb independent activity, and our own unpublished data demonstrates similar independence for other TNFR targeting antibodies. These data suggest, as previously proposed by White et al., that the specific mouse FcyRs involved in cross linking of TNFR agonists may vary depending on the pathway being targeted and on the bioavailability of each of the FcyRs at the primary site of action. The second is the idea that effector function enabled antibodies represent a risk to activity due to depletion of key immune cell sub-sets. Importantly the data highlight the fact that peripheral and intratumoral antibody mediated effector function are far from equivalent. This difference appears to hinge on two critical differences; the level of target antigen expression and the presence of appropriate effector cells (Figure 2).

The extent of effector function triggered by antibody binding has been shown in a number of studies to be strongly influenced by the level of target antigen expression $[37,38]$, with antibodies directed against both human CCR4 and CD20 failing to elicit in vitro ADCC against human tumor cell lines expressing anything less than $10^{4}$ antigen molecules per cell and reaching optimal activity only in the presence of $10^{5}-10^{6}$ antigen molecules [37]. Many of the targets for immunomodulatory antibodies are expressed at low to undetectable levels on resting, peripheral immune cells, but are up-regulated significantly in the presence of pro-inflammatory stimuli, such as those present in the tumor microenvironment. As such, and in the light of recent studies, it is clear that in mouse models it is significantly easier to elicit effector function against intratumoral immune cells. Additionally effector function is entirely dependent upon the presence of FcyR-bearing effector cells at an appropriate density. The studies by both Simpson et al. and Bulliard et al. highlight what many of us will have observed in our own work, that there are very few effector cells, such as NK cells, neutrophils and macrophages, present in lymph nodes, which are dominated by T, B and dendritic cells. What both studies additionally show is that mouse tumors are extremely rich in FcyR-expressing effector cells. Simpson et al. evidence greater than $20 \%$ NK cells and greater than $40 \%$ CD11b + cells, which are predominantly macrophages, in B16 tumors and Bulliard et al. highlight very similar levels of the same cells in CT26 tumors. The coincident presence of high levels of target antigen and a high density of effector cells creates a perfect storm for Fc mediated effector function within the tumor, while the lower target expression and relative paucity of effector cells in the periphery makes the same effector function harder to achieve in the lymph node. It is however worth noting that peripheral depletion of immune cells is possible, as demonstrated by the data on anti-CD40 [13] and the well documented effects of antiCD20 [39], suggesting that the nature or expression level of the target are likely critical.

\section{Translating preclinical data to man}

As outlined at the start of this review, the significant differences between human and mouse FcyR and IgG isotype biology make translation of findings between species extremely challenging, and several factors need to be considered and better studied in the human setting before these findings can be confidently applied to the activity of therapeutic antibodies in man.

Taking anti-CTLA-4 as an example, the first significant translational challenge is the key role for mouse Fc $\gamma$ RIV in the T-reg depleting activity demonstrated for anti-mouse CTLA-4. FcyRIV does not exist in humans, and its closest analog, human (h)FcyRIIIa, is expressed predominantly on NK cells, which played no role in the mainly macrophage mediated T-reg depletion observed with anti-mouse CTLA-4 [33]. In humans macrophages can express hFcyRIIIa following certain stimuli, such as IL-10, but primarily express hFc $\gamma \mathrm{RIIa} / \mathrm{b}$ and hFc $\gamma \mathrm{RI}$, and it is feasible that in human tumors these receptors would play the same role as mouse FcyRIV does in mouse tumors. Further study of the intratumoral effector cell and FcyR constituent within human tumors would be extremely helpful in understanding which human $\mathrm{Fc} \gamma \mathrm{R}$ might play the role of mouse FcyRIV in humans.

The second challenge for translation lies in the differences between IgG isotypes across species. In mice only mouse (m)IgG2a and mIgG2b demonstrate any measurable binding to mouse FcyRIV; mIgG1 can therefore show none of the T-reg depleting activity observed for 

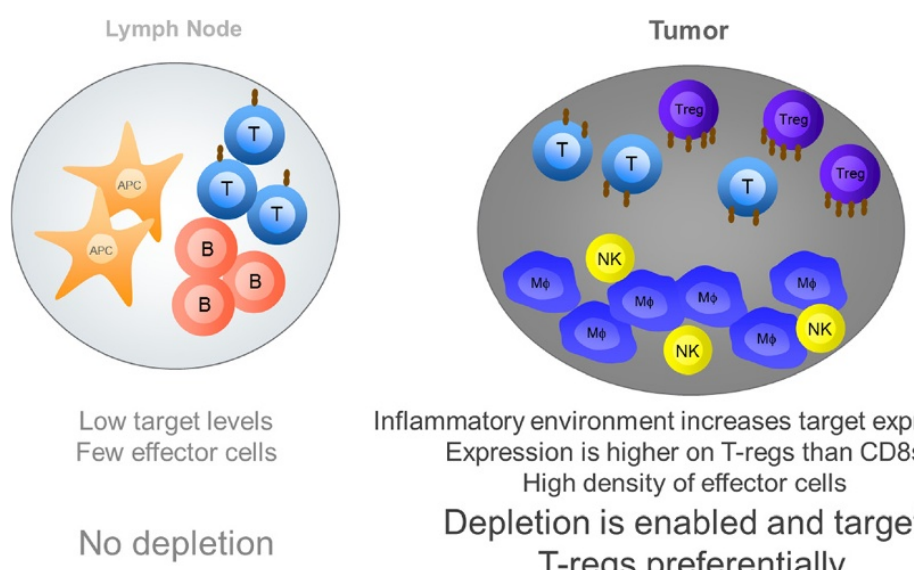

Inflammatory environment increases target expression Expression is higher on T-regs than CD8s High density of effector cells

Depletion is enabled and targets T-regs preferentially

Figure 2 Critical differences between effector function in the periphery relative to the tumor. On the left: in lymph nodes, relatively low levels of cell activation and pro-inflammatory cytokines result in low levels of expression for most targets of immunomodulatory antibodies, which are generally low on resting immune cells. This low level of target expression, together with a paucity of effector cells in lymph nodes means depletion of cells through cell mediated effector functions do not readily occur. On the right: high levels of pro-inflammatory cytokines within the tumor microenvironment trigger up-regulation of many targets. This increased target expression together with a high density of effector cells, such as macrophages, enables depletion of cells through cell-mediated effector functions. The level of target expression, and the sensitivity to depletion varies across cell types and favours depletion of T-regs for targets such as CTLA-4 and GITR.

anti-mouse CTLA-4 in mice. In contrast, while human(h) IgG1 has a significantly higher binding affinity to all human Fc $\gamma$ Rs, hIgG2 and hIgG4 are both capable of interacting with human FcyRIIa and IIIa, and while human FcyRI cannot bind hIgG2, its high affinity for monomeric IgG suggests that it would be heavily occupied by serum IgG and less available to partake in effector function [40]. Critically, while hIgG2 and hIgG4 are both very poor mediators of NK cell driven ADCC, they are both capable of mediating ADCC via PBMCs, monocytes and neutrophils [41,42]. It is especially conceivable that in a tumor microenvironment, with its increased target antigen levels and high density of effector cells, that a hIgG2 or hIgG4 could begin to mediate some degree of ADCC or ADCP. If one were to assume that a mouse IgG2a were equivalent to human IgG1 and mouse IgG1 equivalent to human IgG2 then the data of Selby et al. would predict significant differences in the two anti-CTLA-4 antibodies that have been tested clinically one of which, tremelimumb, is a human IgG2 and the other of which, ipilimumab, is a human IgG1 currently registered for the treatment of metastatic melanoma. The complex differences in Fc $\gamma R$ and IgG isotype biology that exist between species, outlined above, suggest however that such assumptions about the comparability of mouse and human IgG isotypes may be too reductionist. In relation to this, while no definitive comparison of the two agents has been conducted, the toxicity profiles of ipilimumab and tremelimumab are comparable $[19,43]$ and a recent commentary in the Journal of Clinical Oncology [44] highlighted the very limited differences observed in the
3 year survival rate seen in melanoma patients treated with the two agents.

The third translational challenge relates to the key driver for differential depletion of T-regs relative to other cell types in all three of the published studies, that is target expression level. It is clear from the published studies that the levels of GITR and CTLA-4 on mouse T-regs is higher than that observed on mouse effector $\mathrm{T}$ cells, in particular CD8s. However there are no studies available comparing how the level of target expression varies between mice and humans, few that compare the differential expression of target on human T-regs relative to effectors, and none that examine how this expression changes quantitatively in the tumor versus the periphery. These are all significant variables that must be studied in humans before a direct translational conclusion can be drawn.

\section{Conclusions}

\section{Future directions}

Immunomodulatory antibodies are showing positive results in early clinical trials in cancer. These antibodies generally fall into two classes. Those that antagonise inhibitory receptors, such as CTLA-4 and PD-1, and those that agonise stimulatory receptors, such as CD27, OX40, GITR and CD137.

Many groups, including our own, have been working to study the requirement for Fc $\gamma$ Rs in the activity of TNFR agonist antibodies, but the recent study of Bulliard et al. [31] has further highlighted the potential complexity of this requirement by providing evidence that inhibitory mouse 
Fc $\gamma$ RIIb is not required for the activity of all TNFR agonist antibodies in mice, as has been previously suggested. Further work is required to pull apart the target specific nature of $F_{c} \gamma \mathrm{R}$ requirements for mAb activity and the relative contributions of pathway agonism versus targeted depletion of cells. In the case of TNFR agonists pulling these apart is made very difficult by the inability to divorce Fc $\gamma R$ cross linking, and therefore agonism, from effector function for the majority of such antibodies.

The study by Bulliard et al. [31], together with that of Selby et al. and Simpson et al. [32,33], also highlighted the previously underappreciated difference between FcyRmediated effector function in the periphery as compared to the tumor microenvironment in mice and highlighted the unexpected potential role of Fc $\gamma$ Rs in the activity of immunomodulatory antibodies that target the inhibitory receptor CTLA-4 in mice. Based on these studies it will be interesting to see how FcyR interactions may impact antibodies targeting PD-1 or PD-L1, which have very different expression patterns to CTLA-4, despite their shared inhibitory function.

The most important future studies however will be those that address the translatability of these findings in mouse preclinical models to man. While their exact value remains unconfirmed [4], studies exploring the impact of human FcyR polymorphisms on clinical activity may shed further light on how critical individual receptors are to the mechanism of specific immunomodulatory antibodies. To this end a study presented at ASCO in 2013 [45] reported no difference in response to the anti-CTLA-4 ipilimumab in patients with the high versus low affinity allotypic forms of human (h)Fc $\gamma$ RIIIa or $\mathrm{hFc} \gamma$ RIIa. The triggering of effector function is however a complex process; the result of an ill-defined interplay between target expression, IgG affinity for $\mathrm{F} c \gamma \mathrm{R}, \mathrm{F} c \gamma \mathrm{R}$ expression patterns on different leukocytes and density of those leukocytes that mediate effector function, such as NK cells and macrophages. These are all variables which could diverge significantly between species. Ultimately further studies in human in vitro systems and in primary tissue samples, preferably from patients treated with immunotherapy agents, will be the most effective way to determine the comparability of these variables between human and mouse. It is these studies that will serve to move the translation of this key aspect of biology forward and aid in the design of more effective therapeutics.

\footnotetext{
Abbreviations

F(ab): Fragment antigen binding; Fc: Fragment crystallisable; FcyR: Fc gamma receptor; ADCC: Antibody dependent cellular cytotoxicity; ADCP: Antibody dependent cellular phagocytosis; CTLA-4: Cytotoxic T lymphocyte antigen 4 PD-1: Programmed death 1; PD-L1: Programmed death ligand 1; TIM-3: T-cell immunoglobulin domain and mucin domain 3; TNFR: Tumor necrosis factor receptor; GITR: Glucocorticoid-induced TNFR family related gene; KIR: Killer-cell immunoglobulin-like receptor; LAG-3: Lymphocyte-activation gene 3; VISTA: V-domain Ig suppressor of T cell activation.
}

\section{Competing interests}

Ross Stewart and Robert Wilkinson are salaried employees of Medlmmune Ltd. Scott Hammond and Mike Oberst are salaried employees of Medlmmune LLC. All four authors hold shares in the AstraZeneca group.

\section{Authors' contributions}

$\mathrm{RS}, \mathrm{SH}$ and $\mathrm{MO}$ conceived of, planned and drafted the initial content of the article. RS provided all figures. RW provided substantive review. All authors read and approved the final manuscript.

\section{Authors' information}

$\mathrm{RS}, \mathrm{SH}, \mathrm{MO}$ and RW are part of the Oncology research group within Medlmmune where they are involved in the discovery and development of a range of immunomodulatory antibody approaches.

\section{Acknowledgements}

The authors thank Norman Greenberg for careful review of the final manuscript.

\section{Author details}

${ }^{1}$ Medlmmune, AKB Building, Granta Park, CB21 6GH England, UK.

${ }^{2}$ Medlmmune, One Medimmune Way, Gaithersburg, MD 20878, USA.

Received: 14 February 2014 Accepted: 16 July 2014

Published online: 19 August 2014

\section{References}

1. Nimmerjahn F, Ravetch JV: Fcgamma receptors as regulators of immune responses. Nat Rev Immunol 2008, 8:34-47.

2. Bruhns P: Properties of mouse and human IgG receptors and their contribution to disease models. Blood 2012, 119:5640-5649.

3. Tamoutounour S, Henri S, Lelouard H, de Bovis B, de Haar C, van der Woude CJ, Woltman AM, Reyal Y, Bonnet D, Sichien D, Bain CC, Mowat AM, Reis e Sousa C, Poulin LF, Malissen B, Guilliams M: CD64 distinguishes macrophages from dendritic cells in the gut and reveals the Th1-inducing role of mesenteric lymph node macrophages during colitis. Eur J Immunol 2012, 42:3150-3166.

4. Mellor JD, Brown MP, Irving HR, Zalcberg JR, Dobrovic A: A critical review of the role of Fc gamma receptor polymorphisms in the response to monoclonal antibodies in cancer. J Hematol Oncol 2013, 6:1.

5. Bruhns P, lannascoli B, England P, Mancardi DA, Fernandez N, Jorieux S, Daeron M: Specificity and affinity of human Fcgamma receptors and their polymorphic variants for human lgG subclasses. Blood 2009, 113:3716-3725.

6. Nimmerjahn F, Bruhns P, Horiuchi K, Ravetch JV: FcgammaRIV: a novel FcR with distinct IgG subclass specificity. Immunity 2005, 23:41-51

7. Clynes RA, Towers TL, Presta LG, Ravetch JV: Inhibitory Fc receptors modulate in vivo cytoxicity against tumor targets. Nat Med 2000, 6:443-446.

8. Cartron G, Dacheux L, Salles G, Solal-Celigny P, Bardos P, Colombat P, Watier H: Therapeutic activity of humanized anti-CD20 monoclonal antibody and polymorphism in IgG Fc receptor FcgammaRIlla gene. Blood 2002, 99:754-758.

9. Weng WK, Levy R: Two immunoglobulin $G$ fragment $C$ receptor polymorphisms independently predict response to rituximab in patients with follicular lymphoma. J Clin Oncol 2003, 21:3940-3947.

10. Lazar GA, Dang W, Karki S, Vafa O, Peng JS, Hyun L, Chan C, Chung HS, Eivazi A, Yoder SC, Vielmetter J, Carmichael DF, Hayes RJ, Dahiyat BI: Engineered antibody Fc variants with enhanced effector function. Proc Natl Acad Sci U S A 2006, 103:4005-4010.

11. Niwa R, Natsume A, Uehara A, Wakitani M, lida S, Uchida K, Satoh M, Shitara K: IgG subclass-independent improvement of antibodydependent cellular cytotoxicity by fucose removal from Asn297linked oligosaccharides. J Immunol Methods 2005, 306:151-160.

12. Shields RL, Namenuk AK, Hong K, Meng YG, Rae J, Briggs J, Xie D, Lai J, Stadlen A, Li B, Fox JA, Presta LG: High resolution mapping of the binding site on human IgG1 for Fc gamma RI, Fc gamma RII, Fc gamma RIII, and $\mathrm{FcRn}$ and design of $\lg \mathrm{G} 1$ variants with improved binding to the Fc gamma R. J Biol Chem 2001, 276:6591-6604. 
13. Li F, Ravetch JV: Inhibitory Fcgamma receptor engagement drives adjuvant and anti-tumor activities of agonistic CD40 antibodies. Science (New York, NY) 2011, 333:1030-1034.

14. White AL, Chan HT, Roghanian A, French RR, Mockridge Cl, Tutt AL, Dixon SV, Ajona D, Verbeek JS, Al-Shamkhani A, Cragg MS, Beers SA, Glennie MJ: Interaction with FcgammaRIIB is critical for the agonistic activity of antiCD40 monoclonal antibody. J Immunol 2011, 187:1754-1763.

15. Li F, Ravetch JV: Apoptotic and antitumor activity of death receptor antibodies require inhibitory Fcgamma receptor engagement. Proc Natl Acad Sci U S A 2012, 109:10966-10971.

16. Wilson NS, Yang B, Yang A, Loeser S, Marsters S, Lawrence D, Li Y, Pitti R, Totpal K, Yee S, Ross S, Vernes JM, Lu Y, Adams C, Offringa R, Kelley B, Hymowitz S, Daniel D, Meng G, Ashkenazi A: An Fcgamma receptordependent mechanism drives antibody-mediated target-receptor signaling in cancer cells. Cancer Cell 2011, 19:101-113.

17. Xu Y, Szalai AJ, Zhou T, Zinn KR, Chaudhuri TR, Li X, Koopman WJ, Kimberly RP: Fc gamma Rs modulate cytotoxicity of anti-Fas antibodies: implications for agonistic antibody-based therapeutics. J Immunol 2003, 171:562-568.

18. White AL, Chan HT, French RR, Beers SA, Cragg MS, Johnson PW, Glennie MJ: FcgammaRlotalotaB controls the potency of agonistic anti-TNFR mAbs. Cancer Immunol Immunother 2013, 62:941-948.

19. Hodi FS, O'Day SJ, McDermott DF, Weber RW, Sosman JA, Haanen JB, Gonzalez R, Robert C, Schadendorf D, Hassel JC, Akerley W, van den Eertwegh AJ, Lutzky J, Lorigan P, Vaubel JM, Linette GP, Hogg D, Ottensmeier CH, Lebbe C, Peschel C, Quirt I, Clark JI, Wolchok JD, Weber JS, Tian J, Yellin MJ, Nichol GM, Hoos A, Urba WJ: Improved survival with ipilimumab in patients with metastatic melanoma. N Engl J Med 2010, 363:711-723.

20. Hamid O, Robert C, Daud A, Hodi FS, Hwu WJ, Kefford R, Wolchok JD, Hersey P, Joseph RW, Weber JS, Dronca R, Gangadhar TC, Patnaik A, Zarour H, Joshua AM, Gergich K, Elassaiss-Schaap J, Algazi A, Mateus C, Boasberg P, Tumeh PC, Chmielowski B, Ebbinghaus SW, Li XN, Kang SP, Ribas A: Safety and tumor responses with lambrolizumab (anti-PD-1) in melanoma. N Engl J Med 2013, 369:134-144.

21. Topalian SL, Hodi FS, Brahmer JR, Gettinger SN, Smith DC, McDermott DF, Powderly JD, Carvajal RD, Sosman JA, Atkins MB, Leming PD, Spigel DR, Antonia SJ, Horn L, Drake CG, Pardoll DM, Chen L, Sharfman WH, Anders RA, Taube JM, McMiller TL, Xu H, Korman AJ, Jure-Kunkel M, Agrawal S, McDonald D, Kollia GD, Gupta A, Wigginton JM, Sznol M: Safety, activity, and immune correlates of anti-PD-1 antibody in cancer. N Engl J Med 2012, 366:2443-2454.

22. Beatty GL, Chiorean EG, Fishman MP, Saboury B, Teitelbaum UR, Sun W, Huhn RD, Song W, Li D, Sharp LL, Torigian DA, O'Dwyer PJ, Vonderheide RH: CD40 agonists alter tumor stroma and show efficacy against pancreatic carcinoma in mice and humans. Science (New York, NY) 2011, 331:1612-1616.

23. Curti BD, Kovacsovics-Bankowski M, Morris N, Walker E, Chisholm L, Floyd K, Walker J, Gonzalez I, Meeuwsen T, Fox BA, Moudgil T, Miller W, Haley D, Coffey T, Fisher B, Delanty-Miller L, Rymarchyk N, Kelly T, Crocenzi T, Bernstein E, Sanborn R, Urba WJ, Weinberg AD: OX40 is a potent immune-stimulating target in late-stage cancer patients. Cancer Res 2014, 73:7189-7198.

24. Sznol M, Hodi FS, Margolin K, McDermott DF, Ernstoff MS, Kirkwood JM, Wojtaszek C, Feltquate D, Logan T: Phase I study of BMS-663513, a fully human anti-CD137 agonist monoclonal antibody, in patients (pts) with advanced cancer (CA). J Clin Oncol 2008, 26:3007.

25. Morris NP, Peters C, Montler R, Hu HM, Curti BD, Urba WJ, Weinberg AD: Development and characterization of recombinant human Fc:OX40L fusion protein linked via a coiled-coil trimerization domain. Mol Immunol 2007, 44:3112-3121.

26. Vitale LA, He LZ, Thomas LJ, Widger J, Weidlick J, Crocker A, O'Neill T, Storey J, Glennie MJ, Grote DM, Ansell SM, Marsh H, Keler T: Development of a human monoclonal antibody for potential therapy of CD27-expressing lymphoma and leukemia. Clin Cancer Res 2012, 18:3812-3821.

27. van Eenennaam H, Veraar E, Mulder W, Bastiaanssen E, Driessen L, Hulsik DL, Vink P, van der Horst G, Xiao Y, Borst J, van Elsas A: Development of an agonistic antibody against the human T-cell costimulatory receptor CD27 as a potential immunotherapeutic tool. In Book Development of an agonistic antibody against the human T-cell costimulatory receptor $\mathrm{CD} 27$ as a potential immunotherapeutic tool, Cancer Res, Volume 8 Supplement. 73rd edition. 2013:1246

28. Richman LP, Vonderheide RH: Role of crosslinking for agonistic CD40 monoclonal antibodies as immune therapy of cancer. Cancer Immunol Res 2014, 2:19-26.

29. Martinez-Forero I, Azpilikueta A, Bolanos-Mateo E, Nistal-Villan E, Palazon A Teijeira A, Perez-Chacon G, Morales-Kastresana A, Murillo O, Jure-Kunkel M, Zapata JM, Melero I: T cell costimulation with anti-CD137 monoclonal antibodies is mediated by K63-polyubiquitin-dependent signals from endosomes. J Immunol 2013, 190:6694-6706.

30. Oganesyan V, Gao C, Shirinian L, Wu H, Dall'Acqua WF: Structural characterization of a human Fc fragment engineered for lack of effector functions. Acta Crystallogr D Biol Crystallogr 2008, 64:700-704.

31. Bulliard $Y$, Jolicoeur R, Windman M, Rue SM, Ettenberg S, Knee DA, Wilson NS, Dranoff G, Brogdon JL: Activating Fc gamma receptors contribute to the antitumor activities of immunoregulatory receptor-targeting antibodies. J Exp Med 2013, 210:1685-1693.

32. Selby MJ, Engelhardt JJ, Quigley M, Henning KA, Chen T, Srinivasan M, Korman AJ: Anti-CTLA-4 antibodies of IgG2a isotype enhance antitumor activity through reduction of intratumoral regulatory $T$ cells. Cancer Immunol Res 2013, 1:10.

33. Simpson TR, Li F, Montalvo-Ortiz W, Sepulveda MA, Bergerhoff K, Arce F, Roddie C, Henry JY, Yagita H, Wolchok JD, Peggs KS, Ravetch JV, Allison JP, Quezada SA: Fc-dependent depletion of tumor-infiltrating regulatory $T$ cells co-defines the efficacy of anti-CTLA-4 therapy against melanoma. J Exp Med 2013, 210:1695-1710.

34. Bulliard $Y$, Jolicoeur R, Zhang J, Dranoff $G$, Wilson NS, Brogdon JL: OX40 engagement depletes intratumoral Tregs via activating FcgammaRs, leading to antitumor efficacy. Immunol Cell Biol 2014, 92:475-480.

35. Schaer DA, Budhu S, Liu C, Bryson C, Malandro N, Cohen A, Zhong H, Yang X, Houghton AN, Merghoub T, Wolchok JD: GITR pathway activation abrogates tumor immune suppression through loss of regulatory T cell lineage stability. Cancer Immunol Res 2013, 1:320-331

36. Voo KS, Bover L, Harline ML, Vien LT, Facchinetti V, Arima K, Kwak LW, Liu YJ: Antibodies targeting human OX40 expand effector T cells and block inducible and natural regulatory T cell function. J Immunol 2013, 191:3641-3650

37. Niwa R, Sakurada M, Kobayashi Y, Uehara A, Matsushima K, Ueda R, Nakamura K, Shitara K: Enhanced natural killer cell binding and activation by low-fucose IgG1 antibody results in potent antibody-dependent cellular cytotoxicity induction at lower antigen density. Clin Cancer Res 2005, 11:2327-2336.

38. Velders MP, van Rhijn CM, Oskam E, Fleuren GJ, Warnaar SO, Litvinov SV: The impact of antigen density and antibody affinity on antibodydependent cellular cytotoxicity: relevance for immunotherapy of carcinomas. Br J Cancer 1998, 78:478-483.

39. Hamaguchi $Y$, Xiu Y, Komura K, Nimmerjahn F, Tedder TF: Antibody isotype-specific engagement of Fcgamma receptors regulates $B$ lymphocyte depletion during CD20 immunotherapy. J Exp Med 2006, 203:743-753.

40. van de Winkel JG, Capel PJ: Human IgG Fc receptor heterogeneity: molecular aspects and clinical implications. Immunol Today 1993, $14: 215-221$

41. Schneider-Merck T, van Bueren JJ L, Berger S, Rossen K, van Berkel PH, Derer S, Beyer T, Lohse S, Bleeker WK, Peipp M, Parren PW, van de Winkel JG, Valerius T, Dechant M: Human IgG2 antibodies against epidermal growth factor receptor effectively trigger antibodydependent cellular cytotoxicity but, in contrast to $\lg \mathrm{G} 1$, only by cells of myeloid lineage. J Immunol 2010, 184:512-520.

42. Isaacs JD, Wing MG, Greenwood JD, Hazleman BL, Hale G, Waldmann H: A therapeutic human lgG4 monoclonal antibody that depletes target cells in humans. Clin Exp Immunol 1996, 106:427-433.

43. Ribas A, Kefford R, Marshall MA, Punt CJ, Haanen JB, Marmol M, Garbe C, Gogas H, Schachter J, Linette G, Lorigan P, Kendra KL, Maio M, Trefzer U, Smylie M, McArthur GA, Dreno B, Nathan PD, Mackiewicz J, Kirkwood JM, Gomez-Navarro J, Huang B, Pavlov D, Hauschild A: Phase III randomized clinical trial comparing tremelimumab with standard-of-care chemotherapy in patients with advanced melanoma. J Clin Oncol 2013, 31:616-622.

44. Wilson KS, Kotb R: Is tremelimumab beneficial in advanced melanoma? J Clin Oncol 2013, 31:2835-2836. 
45. Korman AJ, Engelhardt J, Shahabi V, Yordanova R, Henning K, Chen T, Selby MJ: Role of the immunoglobulin constant region in the antitumor activity of antibodies to cytotoxic T-lymphocyte antigen-4 (CTLA-4). In Book Role of the immunoglobulin constant region in the antitumor activity of antibodies to cytotoxic T-lymphocyte antigen-4 (CTLA-4), Journal of Clinical Oncology, Volume 15_suppl. 31st edition. 2013:9055.

doi:10.1186/s40425-014-0029-x

Cite this article as: Stewart et al:: The role of Fc gamma receptors in the activity of immunomodulatory antibodies for cancer. Journal for

ImmunoTherapy of Cancer 2014 2:29.

\section{Submit your next manuscript to BioMed Central and take full advantage of:}

- Convenient online submission

- Thorough peer review

- No space constraints or color figure charges

- Immediate publication on acceptance

- Inclusion in PubMed, CAS, Scopus and Google Scholar

- Research which is freely available for redistribution 